\title{
INVESTIGATING FACTORS HINDERING THE IMPLEMENTATION OF E-LEARNING AT MOTHEO TECHNICAL AND VOCATIONAL EDUCATION AND TRAINING (TVET) COLLEGE: A CASE STUDY OF THE NATIONAL VOCATIONAL CERTIFICATE (NCV) PROGRAMME
}

\author{
Mmatau Zwane ${ }^{1}$, \& Wendy N. Setlalentoa ${ }^{2}$ \\ ${ }^{l}$ Department of Post Graduate Studies \\ ${ }^{2}$ Department of Mathematics, Science and Technology Education \\ Faculty of Humanities, Central University of Technology, Free State, Private Bag X20539, \\ Bloemfontein 9300 (South Africa)
}

\begin{abstract}
This study investigated factors that hinder the effective implementation of e-learning at Motheo Technical and Vocational Education and Training (TVET) College, NCV Faculty Bloemfontein Campus by staff members. The study population was all academic staff in the National Vocational Certificate (NCV) Faculty. A purposive sample comprising four Information Technology personnel, two academic management for the Faculty, campus manager and the head of e-learning department was selected. Qualitative data collected through interviews were categorised into themes. The study identified amongst others, factors that hinders the effective implementation of e-learning at Faculty level. These included lack of Information and Communications Technology (ICT) policy and strategic plan, slow internet connectivity, old software, inadequate ICT/compatible resources for e-learning, lack of training of personnel, motivation of staff, ICT skills, and administrative and technical support. The implementation of e-learning could be effective through policy consideration that favor e-learning, motivation among the Faculty, using open source software/updated software, skills development and training, management support, resources accessibility and availability.
\end{abstract}

Keywords: NCV, TVET, e-learning.

\section{Introduction}

Education has been identified as a vital tool for any form of development in any country, companies or individuals. However, teaching is becoming one of the most challenging professions today because of the needy of knowledge acquisition and dissemination. This has seen the emergences and expansion of Information and Communication Technology (ICT) tools in education as teaching and learning tools. E-learning is an ICT tool which offers learners with the ability to fit learning around their lifestyles by sharing materials of all kinds. For example, videos, slideshows, word documents and PDFs (Gamdi and Samarji, 2016). It allows even the busiest person (the working class) to further a career and gain new qualifications in Technical and Vocational Education and Training (TVET). It can play a crucial role in bringing education closer to people and developing a lifelong learning culture by TVET. Meanwhile the benefits of ICT have not been fully utilized by the Motheo Technical and Vocational Education and Training (TVET) College.

\section{Background}

Motheo Technical and Vocational Education and Training (TVET) College is one of the 50 institutions that were formed after merging of different delivery sites in South Africa. It was formed because of the amalgamation of Bloemfontein College, Hillside View College, Thaba 'Nchu College and Kagisong Teachers' College. These delivery sites (campuses) are located at different places. Although they offer the same qualifications, it has been discovered that there are many challenges related to curriculum, administration, and assessment as lectures experience changes in communication as a results of the uncontrollable development of e-learning (Igberadia, 2015; Konayuma, 2015); un-networked campuses that cannot allow resource sharing(hardware, software, media for collection, storage, processing, 
transmission and presentation of information), failure of students to access any type of information such as date of registration, the rules and regulations of the college. Duplication of resources is also a concern at Motheo TVET. For example, information is stored in numerous modes of expression (blackboard; overhead projectors; interactive white board Academic Support Technologies (AST) Tutor). Like students, lecturers do not also have access to backup and sharing capabilities that can assist in classifying and organizing; summarizing and synthesizing; analysing and evaluating; speculating and predicting the gathered and identified information.

The rapid change of ICT tool, e-learning has affected the teaching and learning process. This change has expanded to new learning opportunities and access to educational resources beyond those traditionally available. The expansion to new learning has had an impact on curriculum development and delivery. These impacts pose new challenges for education and training systems Draft White Paper on e-Education (2003:6).

As outlined in Draft White Paper on e-Education (2003:22) e-learning (learning using ICT) is about delivering philosophies and methodologies in the learning environment. Having e-learning as an ICT delivery tool, takes the learners and teachers through the process of exploring what can be done with ICT, how ICT can be used to supplement normal processes or resources. Lastly the way ICT can support new way of teaching and learning. Draft White Paper on e-Education (2003:22) makes it clear that e-learning is not to replace lectures, but to enhance the quality of teaching and reduce the time spend on administrative chores.

\subsection{Objectives of the study}

The following are the objectives of this study:

- To identify the current/existing status of e-learning at Motheo TVET College Bloemfontein Campus NCV Faculty.

- To identify the barriers (if any) that plays a major role in the successful implementation of e-learning at Motheo TVET College Bloemfontein Campus NCV Faculty.

- To formulate strategies for addressing barriers (if any) in implementation of e- learning at Motheo TVET College Bloemfontein Campus NCV Faculty.

\subsection{Research objectives and questions}

The study sought to answer the following questions:

- How is e-learning implemented at Motheo TVET College in Bloemfontein Campus NCV Faculty?

- What are the major barriers for implementing e-learning successfully at Motheo TVET College in Bloemfontein Campus NCV Faculty?

- In what way can the identified barriers to the implementing e-learning in Motheo TVET College in Bloemfontein Campus NCV Faculty be addressed?

\section{Method}

\subsection{Research design}

This is an exploratory case study.

\subsection{Participants and sample}

Purposive sampling technique was used. The sample comprised 26 academic staff, IT personnel, two academic management for the Faculty, campus manager and the head of e-learning department of Motheo TVET College.

\subsection{Data collection}

Data were collected by means of observations and focus group discussions. The study population comprised 41 academic staff, one IT personnel, five academic management for the Faculty, campus manager and the head of e-learning department of Motheo TVET College. All interviews were recorded, transcribed, coded and themes were identified (Leedy and Ormod, 2014; Maree, 2014).

\subsection{Results and discussions}

In response to the question on e-learning initiatives available at the institution, all participants indicated that there was a laptop initiative. One participant quoted verbatim stated that: "It started a few years back when the College started with e-learning and some lecturers where given laptops, were also data projectors installed in different faculties including NCV Faculty so that they can be use in class". 
Another participant said, "it happened about 4-5 years ago and since then no laptop have been allocated". Another one stated that "not all lecturers received the laptops and that data projectors were installed with brackets on but were stolen". Only ten data projectors are allocated to NCV Faculty which is totally inadequate.

Regarding factors which are barriers for the implementation of e-learning at Motheo TVET College, a participant indicated that: "As a computer Lecturer I suggest that computer software at my college be upgraded, serviced to ensure efficient teaching and learning. Adequate training to staff be provided timeously and properly. Monitoring of resources should be conducted at least once a month to ensure proper running and development".

Another response was: "lectures need training in e-learning (blackboard, etc.). Networks (e.g. internet access) is restricted and Coltech is not reliable". Internet is very slow. Wi-Fi is needed in classrooms. Server is not functioning needs to be replaced".

The results identified several factors which are barriers for e-learning to work effectively at Motheo TVET College NCV Faculty Bloemfontein Campus. These include unavailability of working computers (very old computers are being used), lower Internet connectivity, unimproved/expired licensed software, both staff and $90 \%$ of the interviewee not knowing about the appropriate policies favoring e-learning, lack of technical support for e-learning and lack of training for lecturers on e-learning in all levels. The study showed that all staff members were aware, but as for training, concentration was on few lecturers, mainly the ones who were lecturing ICT component (Gamdi and Samarji, 2016). Even though there is no specific institutional ICT policy at work, there is a draft policy.

The findings of this study also indicated that major barriers for adopting e-learning at Motheo TVET College NCV Faculty Bloemfontein Campus were mainly: the lack of training facilities for staff members, lack of ICT skill, lack of motivation and awareness only on those who lecture ICT component, lack of management support, technical support and resistance of individuals to change

As indicated by the participants, to ensure proper implementation of e-learning the following need to be attended to: networking of the e-learning labs, availability of hardware, faster Internet connectivity, improved software, provision of technical support for e-learning.

\section{Conclusion}

The study revealed that lecturing staff are not using the new technology due to a combination of socio-cultural, person logical related factor and the exposure to new technologies. The other barriers which are very essential for a successful implementation of e-learning were lack of administrative management and technical support, lack of management or negligence on controlling the progress on the usage of e-learning and lack of funds on technical supports like equipping the labs with new working computers and continuous maintenance. Such conditions create problems hence the academic staff being demotivated. The implementation of e-learning could be effective through policy consideration that favor e-learning, motivation among the Faculty, using open source software/updated software, skills development and training, management support, resources accessibility and availability.

\section{References}

Draft White Paper on e-Education (2003). Transforming Learning and Teaching through ICT. Department of Education.

Gamdi, M.A.Al, Samarji,A. (2016). Perceived Barriers towards e-Learning by Faculty Members at a Recently Established University in Saudi Arabia: International Journal of Information and Education Technology, 6(1)

Igberadja, S. (2015). Challenges of implementing Technical and Vocational Education and Training (TVET) Curriculum in Delta State Colleges of Education. Educational research and review 4(5): $72-80$.

Konayuma, G.S. (2015). A study of the Enablers and Challenges in the implementation of e-Learning Policies in Technical Eduction, Vocational and Entrepreneurship Training Colleges in Zambia. (Unpublished mini dissertation) University of Cape Town, Cape Town.

Leedy, PD., and Ormrod. (2014). Practical Research: Planning and Design. $10^{\text {th }}$ ed. New Jersey: Pearson Education Limited.

Maree, K. (2014). First steps in research. Pretoria: Van Schaik Publishers. 